\title{
A Single, Huge, Aramaic Spoken Heretic: Sequences of Adam's Creation in Early Rabbinic Literature.
}

\author{
Willem Smelik
}

Since God created humans after his own likeness, male and female, it was only natural for Jewish exegetes to imply that the first human, or "First Adam," once was an androgyne as huge as its own Maker. The concept of a macrocosmic God, widespread in the ancient world, ${ }^{2}$ implied a similar gigantic size and shape of the First Adam. Due to the original sin, Adam's stature was not to last, but the myth of its original immensity and subsequent reduction to size received ample attention in rabbinic literature-and underlies the references to Adam in the three texts of the Mishna, the Tosefta and the Babylonian Talmud studied here: m. San. 4:5, its toseftan parallel in t. San. 8.2-9 and the reception in b. San. $38 \mathrm{~b} .{ }^{3}$ The way these latter texts select and sequence, and thereby resignify and embed these Adamic traditions, is the subject of the present essay. This is an argument about form-about the malleability of textual traditions which were transmitted en bloc-and about the way changed form shapes new meaning-about the expression of new content in the process of reshaping pre-extant text blocks.

\footnotetext{
-Earlier versions of this article were delivered at the Winter Meeting of the SOTS, Birmingham, 4-6 January 2006; the Annual SBL meeting, Midrash session, Washington DC, 18-21 November 2006; and at The St Andrews Symposium for Biblical and Early Christian Studies, 2-3 June 2014. In the following, "Mishna" denotes the document with that name, whereas "mishna" stands for a numbered unit in the former.

${ }^{1}$ For the myth of the gigantic androgyne, see S. Niditch, "Cosmic Man as Mediator in Rabbinic Literature," JJS 34 (1983): 137-146; A. Altmann, "The Gnostic Background of the Rabbinic Adam Legends," JQR 35 (1944-1945): 371-391; B. Barc, “La taille cosmique d'Adam dans la littérature juive rabbinique des trois premiers siècles après J.-C.," Revue des Science Religieuse 49 (1975):173-185; E.E. Urbach, The Sages: Their Concepts and Beliefs (Jerusalem: Magness Press, 1975), 225-232; D. Boyarin, Carnal Israel: Reading Sex in Talmudic Literature (Berkeley: University of California Press, 1993), 31-46; D. Aaron, "Imagery of the Divine and the Human: On the Mythology of Genesis Rabba 8 §1," The Journal ofJewish Thought and Philosophy 5 (1995): 1-62. Cf. H. Baumann, Das doppelte Geschlecht: Ethnologische Studien zur Bisexualität in Ritus und Mythos (Berlin: Reimer, 1955). For the Indo-european roots of the androgyne myth, see Shai Secunda, "The Construction, Composition and Idealization of the Female Body in Rabbinic Literature and Parallel Iranian Texts: Three Excursuses," NASHIM: A Journal of Jewish Women's Studies and Gender Issues 23 (2012), 6o-86.

$2 \quad$ A. Damsma, The Targumic Toseftot to Ezekiel (SAIS 13; Leiden: Brill, 2012), appendix E, "The Concept of the Macrocosmic Body in the Ancient Near East", pp. 197-209.

3 The Yerushalmi also discusses the Mishna but its contribution is not relevant for the present discussion, nor are other passages that refer to the primordial Adam but not the .
} 
The following topics will structure the present chapter:

1. The Mishna in San. 4.5 offers two interpretations of a scriptural verse (Gen 4:10), but only the first seems relevant to the halakhic topic under discussion. Apparently the second interpretation slipped into the text as an alternative, but peripheral, take on the same biblical verse without further relevance for the discussion. Yet the question may be raised why it was included if indeed it interrupts the flow of the unit, or how both interpretations function together within the mishna-unit?

2. They are followed by a series of four teachings based on the singular creation of the first ever human being, known as 'Adam the First'. The motifs of this section have many parallels in rabbinic literature and beyond, but the series in the Mishna appear to be 'their own text', that is, making a point independent of the former meaning these traditions may have had.

The mishnaic version can be fruitfully contrasted with the parallel in the Tosefta (t. San. 8.3-6) which likewise offers a series of statements on Adam's singular creation, but despite obvious similarities, the text differs in wording, sequence and framing.

3. The Talmud includes four statements attributed to Rav Yehuda in the name of Rav (b. San. 38b) concerning 'Adam the First' in its discussion of this mishna. These statements are introduced by a mnemonic marker, but what these four traditions do at this point in the tractate is unclear, and how they relate to the Mishna opaque. Accordingly, these four traditions may be conceived as just another series of statements concerning the first human, which stole their place into the text by mere associative force.

4. The four statements in the name of Rav make new points about Adam's singular creation. Adam, we read in quick succession, was a project which the angels were not very keen to see through, his initial dimensions were gigantic, he spoke Aramaic and he was a heretic. Exactly how do these points relate to one another or to the traditions about Adam's singular creation?

Scholars have not been slow to seize upon the many parallels to the rabbinic creation narratives of the first human within and without rabbinic literature. ${ }^{4}$ The origins of the various motifs in pagan and gnostic mythology have long been identified, with due attention to either rabbinic resistance to, or 
adaptation and resignifying of such borrowings. ${ }^{5}$ At many places in rabbinic literature, quotations of and references to the mythological matrix of the first human being have been made in a piecemeal fashion. Many of these motifs appear to have floated around in the oral and written culture of late antiquity and Sages sometimes selected those parts from this vast array of traditions which proved useful for their arguments. ${ }^{6}$ Conversely, other selections seem to have no bearing on the halakhic topic under discussion, but found their way into the text by associative force or because the traditions were memorised in block fashion, so that the quotation of a relevant part of a given block resulted in the inclusion of the whole block. Both these phenomena require further examination.

My focus in this essay is not on the myth per se, but on the two related phenomena of the literary reassignment of motifs and the peripheral accumulation of associated traditions. Whatever the origin of certain traditions - and in the underlying case, speculation about anti-Gnostic or antidualistic tendencies has been rife-they may well have been used as readymade blocks which were realigned to serve new purposes, divested of their original impetus. More precisely, in what follows I will focus on the selection and arrangement of motifs in block transmission to address particular legal situations as well as the apparent tangential presence of similar motifs, which seem to digress from the topic and to have been included by sheer associative force alone. But to assume that the rabbinic fabric of literature is always one of loose association, in which one tradition evokes another, is to underestimate the literary finesse of those who shaped the texts as we know them.

\section{Recontextualizing Genesis 4:10, twice}

Mishna Sanhedrin 4:5 highlights the importance of precise and considered evidence in capital cases. It details how to caution would-be witnesses, outlines what counts as reliable evidence and what does not, such as conjecture and hearsay. To underline the gravity of evidence in capital cases, these witnesses are to be told in no uncertain terms what depends on their evidence. If the accused is sentenced to death based on inaccurate or false evidence, the consequences are irreversible and fatal. Besides, not only could the life of the accused be lost by unwarranted evidence, but also that of her or his potential progeny. Support for this halakhic position is adduced in the form of scriptural interpretation of Gen 4:10 in the Cain and Abel episode:

\footnotetext{
5 David Aaron argued for a mythological matrix that surfaces in Bereshit Rabbah $\S 8$ and that demonstrates rabbinic awareness of and familiarity with non-rabbinic myth in their full-fledged form ("Imagery of the Divine," 1-62).

$6 \quad$ Cf. I. Jacobs, The Midrashic Process: Tradition and Interpretation in Rabbinic Judaism (Cambridge: Cambridge University Press, 1995), 2.
} 
For so we find in the case of Cain who slew his brother, as it is said, "The bloods of your brother cry" (Gen 4:10).

It does not say, "the blood of your brother" [in the singular] but "the bloods of your brother" [in the plural] —his [own] blood and the blood of all those who were destined to be born from him.

Another point: "The bloods of your brother"-[it is written in the plural] because his blood was spattered on trees and stones. ${ }^{7}$

In the Hebrew verse the plural construct ending of the word 'blood' signals the spilled status of Abel's blood, just as other plural forms of disintegrated substances denote their decomposition. ${ }^{8}$ The anonymous voice of this mishna on the other hand relates the plural form to plural instances of bloodshed, namely the blood of both Abel and his children had he lived to produce them. In addition to Abel's death, the Mishna lays Abel's virtual but now foiled offspring to Cain's door. ${ }^{9}$ In doing so it makes a point that resonates in a court of law. The blood of the innocent victim and his progeny cries out, be it the murder victim in Genesis or the victim of false evidence in court. Scripture, it is argued, issues a warning which mirrors and justifies the halakhic point that the bloodline of one who is killed without justification (be it the victim or a falsely convicted suspect) are held against the witnesses, because the verse does not employ the singular for the noun "blood" (ד).

By contrast, in the second interpretation the plural of "blood" points to the many places splashed with blood. ${ }^{10}$ This reading underlines the severity of the killing, but not the plurality of lost souls and for that reason it has no part to play in imparting the grave consequences of any inaccurate testimony on would-be witnesses. It appears to have no thematic link to the topic of the questioning of witnesses and to have little, if any, merit for the halakhic

\footnotetext{
7 The translation is loosely based on J. Neusner, The Mishnah: A New Translation (New Haven:Yale University Press, 1988). Wherever MS Kaufman deviates from the Albeck edition, I have followed the former. For the latter, see C. Albeck, ששה סדרי משנה (6 vols.; Jerusalem: Bialik Institute; Tel-Aviv: Dvir, 1959).

8 B.K. Waltke and M. O'Connor, An Introduction to Biblical Hebrew Syntax (Winona Lake: Eisenbrauns, 1990), 119-120 (§ 7.4.1). Note, however, that the use of the plural for the singular has long been considered a feature of Late Biblical Hebrew, see the literature mentioned in D.-H. Kim, Early Biblical Hebrew, Late Biblical Hebrew, and Linguistic Variability: A Sociolinguistic Evaluation of the Linguistic Dating of Biblical Texts (Leiden: Brill, 2013), 16, 32.

9 The same exegesis is found in Targum Onqelos, Neofiti, the Cairo Geniza Targum and the Fragmentary Targum to this verse, but not in Targum Pseudo-Jonathan which appears to highlight the quantity of blood. See further see A. Samely, The Interpretation of Speech in the Pentateuch Targums: A Study of Method and Presentation in Targumic Exegesis (TSAJ, 27. Tübingen:J.C.B. Mohr [Paul Siebeck], 1992), 170, 290-291.

10 The gemara of b. San. 37 b suggests a similar reason for the plural number: the infliction of several bleeding wounds.
} 
argument." On this assumption, the second interpretation was probably included in the Mishna as the almost random result of the way these interpretative traditions were transmitted and applied to halakhic topics. These two interpretations may have constituted a unit of interpretation of the scriptural verse (Gen 4:10) which was inserted at this point into the halakhic discussion because the first part was pertinent to the mishna's topic, regardless of the irrelevance of the second tradition that followed.

All this begs the question why the second interpretation was not deleted, or conversely, whether the selection and inclusion of this seemingly inapplicable scriptural interpretation might after all have some function in its present cotext. The tendency to preserve traditions for later generations, in an almost antiquarian sense, might be one reason. Learning both interpretative takes on the verse together serves the memory well. But on this occasion we have reason to assume that the second interpretation actually counteracts the halakhic conclusions that were achieved on the basis of the first interpretation. ${ }^{12}$

Elsewhere in the Mishna the reticence to reach a guilty verdict in capital cases is forcefully expressed. According to m. Mak. 1:10, ${ }^{13}$ a sanhedrin is called murderous when it imposes the death penalty "once in seven years," or even "once in seventy years." ${ }^{14}$ Capital punishment requires hermetic proof; these rabbis clearly feel any case will fall short of that demand. R. Tarfon and R. Aqiva even go so far as to claim that they would never reach the guilty verdict in capital cases: "If we were on a sanhedrin, no one would ever be put to death." One can hardly carry this argument any further. But the same mishna continues with the opposite opinion of Rabban Simeon b. Gamaliel, who counters, "So they would multiply the number of murderers in Israel." The downside of a $d e$ facto abolishment of the death penalty, he argues, is the lack of a deterrentthe punishment meted out to murderers keeps a check on would-be killers.

${ }^{11} \quad$ So P. Kehati's commentary in משניות מבוארות (Jerusalem: Mishnayyot Kehati, 2001), vol. 27, p. מח; A. Samely's online database of Midrashic Units in the Mishna, http://mishnah.llc.manchester.ac.uk/detail.aspx?id=448, retrieved 28 May 2014).

12 The Tosefta (t. San. 8:2-3) does not include this scriptural proof text, but offers a famous case-study which is an equally forceful teaching about circumstantial evidence. Even if a witness saw the accused follow the victim in a shop, and the witness later found the victim dead with the accused holding the murder weapon, a knife, in his hand, he should not jump to conclusions: he did not actually see it happening, so his testimony is not valid. Thus the Tosefta highlights the need to rely on actual observations, not on reasoned arguments. A similar tradition found its way into the Babylonian Talmud.

13 For the academic reception of this passage, see B.A. Berkowitz, Execution and Invention: Death Penalty Discourse in Early Rabbinic and Christian Cultures (Oxford: Oxford University Press, 2006).

${ }_{14}$ Obviously, these discussions were of academic value only; see C. Hezser, The Social Structure of the Rabbinic Movement in Roman Palestine (Tübingen: Mohr Siebeck, 1997), 462. 
A similar counter-argument occurs in the final part of this mishna. When it returns to the admonishment of witnesses, it no longer addresses the issue of false or unreliable evidence in capital cases, but the need to come forward and assume responsibility:

Now perhaps you [witnesses] would like now to say, What business have we got with this trouble?

But it already has been written, 'He being a witness, whether he has seen or known, if he does not speak it, then he shall bear his iniquity' (Lev 5:1).

And perhaps you might want to claim, What business is it of ours to convict this human of a capital crime?

But has it not already been said, 'When the wicked perish there is rejoicing' (Prov 11:10)?

The Mishna highlights the fact that withheld evidence is tantamount to sin and deprives the world from rejoicing over the destruction of the wicked. The reticence to provide uncertain evidence, or even to sentence someone to death at all, expressed so forcefully in both mishnayyot (m. Mak. 1.10; San. 4.5), is balanced by the acknowledgment that it is a good thing to establish guilt whenever possible and to hold the wicked to account. On this interpretation, the mishna does not argue against the death sentence unequivocally but imbues witnesses with the gravity of any such verdict. It first deals with the case of a wrongful conviction based on flawed testimonies, then with that of a failed conviction when witnesses do not assume their responsibility and murderers go unpunished.

The two scriptural interpretations represent the pivot of the discussion, as they come exactly in between the two sides of the issue. This position within the unit is not by chance. In brief, the mishna makes the following points in succession:

How to caution witnesses in capital cases

Conjecture and hearsay on the part of witnesses are unacceptable

On false evidence, in capital cases innocent blood is held against you

Proof text: Gen 4:10; "the bloods of your brother" Another interpretation: spattered blood all around

Therefore Adam was created alone (4 reasons)

Relevant testimony may not be withheld

It is a joy when the wicked perish on the basis of given evidence

This sequence places the second interpretation of Gen 4:10 at the heart of the unit. This position may well suggest that it not merely slipped in by associative force, but was selected, intentionally, as it anticipates the final point 
made in the mishna, namely, that evidence to hold the wicked to account must not be withheld. Those who do, bear their own iniquity. ${ }^{15}$ Even though their testimony may lead to another death, this fate of the rightfully convicted leads to joy (citing Prov 11:10). In this second use of the proof text, Abel's blood cries out for justice: a crime so vicious and unmistakable, with visible signs all over the place, calls for a conviction when reliable evidence is available. At this point the victim of the crime is at the center of our attention, rather than the accused who might be wrongly convicted. No witnesses should shirk away from their responsibility if they can contribute to justice. On this reading, the second interpretation is not an immaterial interpretation that happened to follow in this mishna in the slipstream of the first, stranded in the text for no other reason than that it dealt with the same proof text. Rather, both interpretations are evoked to employ their potential for admonishment.

This conclusion is supported by the block of reasons for Adam's solitary creation in this mishna. Homiletically, the mishna restates its concern for the caution required from witnesses in capital cases, by drawing four inferences from Adam's solitary creation. The first of these restates the two sides of the coin discussed so far:

Therefore Adam was created singly, to teach you that whoever destroys a single soul ${ }^{16}$ is deemed by Scripture as if he had destroyed a whole world. And whoever saves a single soul ${ }^{17}$ is deemed by Scripture as if he had saved a whole world.

This first and main inference reflects the preciousness of life which works two ways. To provide unreliable evidence that results in a capital punishment would be to destroy a world, namely that person and any potential offspring, and by the same token evidence that may lead to an acquittal could save an accused person from capital punishment. The context is still that of would-be witnesses in capital cases. Yet the destruction of a world simultaneously applies to the culprit, who destroyed not just a single soul, but an entire world: the gravity of unlawful killing is such that no one should withhold pivotal evidence that might lead to the accused's sentence. The inclusion and position of the second interpretation of Gen. 4.10 reflects the polar aims of the instruction to witnesses, with the admonition to come forward providing a counterpart to the admonition not to give unreliable testimony. Intrinsic to the mishnaic text is the inclusion of interpretative alternatives to draw on.

$15 \quad$ Lev 5:1 in the part that is not cited.

16 Albeck, ששה סדרי משנה adds מישראל at this point, absent in MSS Parma 3173,

Kaufman A5o and Munich 95, but supported by Florence II.I.8-9 and Yad HaRav Herzog 1.

${ }_{17} \quad$ Here again the plus מישראל is found in the same witnesses as before. 


\section{The One and Only, twice}

Behind the biblical narrative of Adam and Eve's creation lurks a world of suggestion and danger. As narrated in the opening of the Book of Genesis, the story has an unmistakable, purposeful ambivalence. In the plural, God creates Adam as a singular (1.26). However well explained, on first acquaintance the

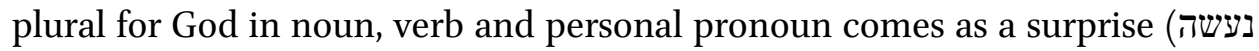
(אדם בצלמנו כדמותנו (ארו ), but so does his single creation. Humankind may be a single item, but they are one as male and female (1:27, ברא אתו זכר ונקבה). God created "him" first in "our" image, then in "his" image (1:27, בצלמו זכרונר), "male and female he created them" (1:27, ברא אתם). This alternation of plurals and singulars, with singulars denoting human plurals (male and female) and plurals denoting divine singulars (God), cannot have failed to provoke a reaction from the audience. Even on the assumption that those familiar with its recitation would have had all such details inculcated in their minds, so that they knew what was to come, their knowledge hardly lessens the textual effect.

Why resort to this bolting series of alternative numbers and contrasting subjects, taking unexpecting readers unawares? To state that God is neither singular nor plural whereas humankind is God's single creation, not the handiwork of multiple gods. The biblical author is not so much staging a silent pre-emptive attack on polytheism, although it leaves no room for that, but sets the philosophical stage for the unique insistence on a single deity in a pluriform world. His is a statement about the unique character of God as the single origin of pluriformity.

In several sources the rabbis took the hint and expanded on the relation between unicity and pluriformity, and above all the creation of Adam as a single being elicited moral reflections on humankind. The proof text and the block on the creation of Adam as a solitary being in m. San. 4:5 is one of the first preserved traditions of this kind, although it may well reflect a relatively late stage in the Mishna's redaction. ${ }^{18}$ For the relationship between the talmudic reception and this mishna, the issue of its relative lateness is irrelevant, since the Talmud presupposes the extant Mishna on this occasion. If both

\footnotetext{
18 The last mishnayyot of chapters, and the very last chapter in tractates in particular, are known to have been subject to later (aggadic) supplementation. For this phenomenon in Mishna and Talmud, see J.N. Epstein, מבוא לנוסח המשנה (Jerusalem: The Hebrew University Magnes Press, 2001), 974-979; Ch. Albeck, Untersuchungen über die Redaktion der Mischnah (Berlin: C.A. Schwetschke, 1923), 134-135; idem, Einführung in die Mischna (Berlin: De Gruyter, 1971), 182-188; A. Weiss, על היצירה של הסבוראים (Jerusalem: Magnes Press, 1953), 8-11, 16; D. Noy, "The Aggadic Endings in the Tractates of the Mishnah," Mahanayyim 57 (1961): 44-59; A. Cohen, Rereading Talmud: Gender, Law and the Poetics of Sugyot (Atlanta: Scholars, 1998), 164; Samely, Rabbinic Interpretation, 19-20.
} 
components of the present mishna reflect secondary growth, the issue of how the Mishna deploys its traditions would apply to this later stage of editorial activity. That we are dealing with a late stage seems to be born out by a closer comparison of the block of four reasons for Adam's solitary creation with the Toseftan parallel. The Mishna reads as follows:

Therefore Adam was created alone,

1. to teach that whoever destroys a single soul ${ }^{19}$ is considered as if he had destroyed a full world. And whoever saves a single soul ${ }^{20}$ is considered as if he had saved a full world;

2. in view of peace among creatures, so that someone should not say to his fellow, My father is greater than your father;

3. so that the heretics ${ }^{21}$ should not say, There are many domains in Heaven;

4. to declare the grandeur of the supreme King of kings, the Holy One, blessed be He. For a person mints a hundred coins with a single seal, and they are all alike one another. But the supreme King of kings, the Holy One, blessed be He, minted all human beings with the seal of the first person, yet not one of them is like anyone else. Therefore each and everyone must say, For my sake the world was created.

These four points draw out different implications from the biblical verses against a textual and exegetical background that is not elaborated. To follow the point, the reader must already know that Adam was created singly; the point itself is not justified by a reference to Gen 1:26-27 on which the tradition is based.

That the text presupposes more than a modicum of familiarity with certain creation narratives also follows from the fact that the first two reasons draw on the notion of Adam the First as a world-spanner, whose size is equal to that of the world, a motif far more elaborately employed in other rabbinic parallels, notably Ber. R. §8. Whatever the origins of this motif, the Mishna here employs it in a novel way, oblivious of any connection with any matrix. There is no doubt that these teachings are borrowed from elsewhere. But the mishna makes good use of the motif, and regardless of any polemic or pagan origin of the detail, the force of this passage is an ethical teaching about the value of human life. Like God is unique and one, so every human being is unique. The final sentence of the fourth reason returns and responds to the first: all individuals have to maintain that the world was created on their account. Thus

\footnotetext{
19 See n.15 above for the plus מישראל in some witnesses.

${ }^{20}$ See n.15 above for the plus מישראל in some witnesses.

${ }^{21}$ This word has been erased from MS Kaufman A50, but is still discernible in the resultant space, with support of the other witnesses.
} 
the equation Adam = world is an ethical imperative, which encapsulates the whole block of four reasons.

Still, the third and fourth reason remind of another concern. While the first two reasons draw inferences for humanity from Adam's single creation, the last two draw conclusions for our understanding of God as the single, unique Creator. The heretical belief in multiple powers in heaven is rejected on the ground of God's likeness to Adam, who was unique. Gen 1:26-27 again lurks prominently in the background of these traditions.

At this juncture the parallels in the Tosefta are instructive. The proposition about the heretical claim that God was not alone in creation occurs there as well, but in another position, based on the observation that Adam was created at the very end of creation (8:7) to forestall any assumption that Adam might have been involved in the creation. Like the Mishna, the Tosefta lists four reasons captured under the heading that Adam was created singly, but without the Mishna's emphasis on the value of a human life (t. San. 8:4-5): ${ }^{22}$

Adam was created singly in the world. Why was he created singly in the world?

1. So that the righteous should not say, We are the children of the righteous one, and so that the evil ones should not say, We are the children of the evil one.

2. Another interpretation. Why was he created singly? So that families should not quarrel with one another. For if now, that Adam was created singly, they quarrel with one another, how much more had there been two created at the outset.

3. Another interpretation. Why was he created singly? Because of the thieves and robbers. If now, that Adam was created singly, people steal and rob, had there been two, how much the more so.

4. Another interpretation. Why was he created singly? To show the grandeur of the King of the king of kings, blessed be He. For with a single seal He created the entire world, and from a single seal all those many seals have come forth, as it is said, 'It is changed as clay under the seal, and all these things stand forth as in a garment' (Job 38:14).

Unlike the Mishna, the first notion in the Tosefta is not that any individual is tantamount to an entire world: Adam was created singly to prevent that people would claim having either a righteous or an evil ancestor. This denial of two ancestors representing good and evil addresses the heretical claim that two

${ }^{22}$ This tradition is supported by MSS "Erfurt" Or. fol. 1220 (Berlin, Staatsbibliothek Preussischer Kulturbesitz), Berlin Or. fol. 1220, and Vienna Heb. 20 (National Library, for up to half of 8:4, after which there is one folio missing). 
powers reside in heaven and that people's inclinations are all predestined. Indeed, the Talmud cites a barait $^{23}$ that is very similar to the Tosefta, except that it starts with the argument of the heresy of the two powers in heavenwhich the Tosefta does not cite-followed by the argument of a righteous or evil ancestor. ${ }^{24}$ This argument develops the notion of the single power in heavens to the absence of predestination in good and evil.

The closest parallel is in both texts' fourth reason, where the differences are as revealing as the similarity. In the mishna, the final statement makes an explicit link with the first reason by way of inclusion - that humanity is unique, and each individual a world unto its own. By contrast, the Tosefta does not hark back to the first reason, but offers a proof text instead (Job 38:14) with which it continues (Job 38:15; t. San. 8:6) in following additions not found in the Mishna (t. San. 8:6-9). This proof text takes Adam as an entire world: "For with a single seal He created the entire world," sparking a multitude of distinct seals. ${ }^{25}$

The question is, then, how these versions relate to one another. In recent years the relationship between Mishna and Tosefta has attracted renewed attention and the idea that the Tosefta preserves or reflects an older version of the Mishna has gained ground, especially where the Tosefta offers a literary parallel to what is found in the Mishnah. ${ }^{26}$ To appreciate the interrelationship between them, whilst leaving the question of their interrelationship open, it is necessary to evaluate whether the Tosefta responds to an earlier version of the mishna and if so, how this earlier version might relate to our present mishna.

It comes as no surprise that the level of editing is strikingly different between Mishna and Tosefta. In the Mishna, the block is well embedded by a topical link to the whole mishna in the first and fourth reason. Conversely, in the Tosefta the Adam-block appears out of the blue and there is little reinforcement of the links between the units in the chapter. Its relationship to the previous toseftas, including topics as the composition of the Sanhedrin, the admonishment of witnesses, and the case of the suspected pursuer, is disjunctive. There is no logical connection between these toseftas and Adam's solitary creation;

\footnotetext{
${ }^{23}$ That is, a non-mishnaic tradition attributed to the Tannaim.

${ }^{24}$ The Talmud's baraita enlists all four arguments of the Tosefta, yet preceded by the Mishna's third argument about the two powers in heaven.

${ }^{25}$ The proof text of Job 38:14-15 is connected to Adam HaRishon in other midrashic texts (cf. Ber. R. 12:6; 11:2; Vilna edition).

תוספתא עתיקתא: ליחס מקבילות המשנה והתוספתא [א] - כל כתבי הקדש (שבת S. Friedman, (ט, Tarbiz 62 (1992/1993): 313-338; A. Houtman, Mishnah and Tosefta: A Synoptic Comparison of the Tractates Berakhot and Shebiit (Tübingen: Mohr Siebeck, 1996); J. Hauptman, Rereading the Mishnah: A New Approach to Ancient Jewish Texts (Tübingen: Mohr Siebeck, 2005); E.S. Alexander, Transmitting Mishnah: The Shaping Influence of Oral Tradition (Cambridge: Cambridge University Press, 2006); R. Brody, Mishnah and Tosefta Studies (Jerusalem: The Hebrew University Magnes Press, 2014), 111-154.
} 
without recourse to another text, to which the Tosefta responds, the text is incoherent to the point of incomprehensibility.

To create sense from the Tosefta's change of subject between 8:3 (the pursued person suspected of committing murder) and 8:4 (Adam's solitary creation), we must assume a missing link in the Tosefta's silent proto-text, with which it might well be in dialogue, but which it failed to include. Accordingly, this proto-text must have included a bridge between the unlawful killing of a person and Adam's singularity. The reconstruction of this link is not impossible. Since the Tosefta argues that many lives follow from a single seal (Adam; 8:4), it stands to reason that this link consisted in the following notion: like Adam, either Abel or the suspect sentenced to death because of unreliable evidence would have brought forth many "seals" had he not been killed. It seems plausible that the Tosefta responds to either the proof text of Abel, who was murdered, or the inference that a wrongfully convicted murder suspect equals a world, as he would have produced many unique seals had he not been sentenced to death.

To evaluate both options, the Tosefta's match with either option is illuminating. The Tosefta carries the argument that many seals come forth from a single unique seal as the final point of its four reasons, but it has no obvious link to the notion that a murdered person or one sentenced to death would also have produced many children. The link would, moreover, only occur in the final position of the block, after three unconnected traditions about Adam's singular status, which does not strengthen its topical link. Conspicuously enough, the Tosefta's first explanation would seamlessly follow the Cain and Abel proof text: "So that the righteous should not say, We are the children of the righteous one, and so that the evil ones should not say, We are the children of the evil one" (read Abel and Cain for the righteous and evil one). Despite the lack of framing in the Tosefta, there is a red thread linking its four explanations of Adam's creation. The common ancestor of Cain and Abel, which unites rather than divides their progeny, also tempers the level of enmity between people and crime (reasons 2 and 3 ). The fourth reason links both their diversity and their common origin to God.

If the proof text came first, the Tosefta would seem to have supplemented this text with a homily on the common ancestry of Cain and Abel, culminating in the notion that a single life is tantamount to an entire world. But what about the Mishna? Discarding the option of polygenesis for the four reasons that Adam was created singly, it seems far more likely that the Mishna adopted and reworked the Toseftan block than vice versa. The Mishna recognized the potential of the Tosefta's last reason; its partial reduplication of the notion that a single being represents a whole world seems best explained by the assumption that the editor(s) moved the final notion to the prominent first position, adding a final note as an inclusio. This rearrangement emphasized the 
importance of earnest and reliable evidence, although the direct connection in the Tosefta between Cain and Abel as arguments for two different Creators was replaced by a dissociated reference to the heretical claim of multiple powers in heaven.

To recapitulate, the Mishna used ready-made blocks that are similar to how the Tosefta's text reads, but the editors retouched the unit, and the retouched format tells a new story: it is explicit about the two applied interpretations of Gen. 4.10 and it rearranges the sequence of teachings about Adam's single creation.

\section{A mnemonic in the Talmudic commentary}

The reception history of the Adam-block in the Mishna and Tosefta continues in the Babylonian Talmud, which has a cluster of traditions which takes it up and supplies additional teachings. The talmudic commentary selects a number of elements of m. San. 4:5, in their given order but with the usual digressions. These elements do not necessarily follow the main structure of the Mishna and can, roughly, be divided into five uneven parts: ${ }^{27}$

-what is conjecture (in relation to partial but crucially incomplete witnessing);

-the implication of Cain's narrative-his subsequent wandering;

-the four reasons that Adam was created alone;

-the fourth reason (to show God's greatness);

-the joy (or not) about the downfall of the wicked (esp. Ahab and Ovadya).

These topics trigger sometimes lengthy digressions about the exile and heretics (including dialogues between Roman emperor[s] and rabbis), while in other ways the Amoraim cited here do not take issue with elements that Mishna included.

The opening of the mishna juxtaposes conjecture with hearsay in the sense of a rumour or as a report from another witness, no matter how reliable that witness might appear to be. The Talmud does not dwell on hearsay, but does, and vividly so, illustrate the problem of conjecture with a narrative about a defendant who was seen holding a blood-stained knife in his hand near a murdered person. ${ }^{28}$ It relates this famous story to the mishnaic distinction between capital and monetary cases. Likewise, the gemara (the Amoraic commentary of the Mishna in the Talmud) silently passes over the Mishna's first interpretation of Gen 4:10, about Abel and his foreclosed offspring, so

${ }^{27}$ Roughly: following the topics and keywords, as well as brief quotations of the Mishna (bypassing the question whether or not these are original). The parts are uneven in length.

${ }_{28}$ A Tannaitic tradition also attested in t. San. 8:3; see further y. San. 4:12(5), 22b. 
pivotal to the argument of true testimony, whereas it comments on the second interpretation that highlights the splashing about of Abel's blood until he dies.

In the wake of Cain's punishment, the Talmud introduces the motif of exile on the ground of his fugitive and wandering status (Gen 4:14), which triggers reflections on the potential of exile for atonement. This potential is illustrated by Cain's life (based on Gen 4:16), and the gemara continues with further topics related to the exile, including the date of the destruction of the Second Temple.

Following the theme of exile, the gemara dwells on the Mishna's four reasons for Adam's single creation. Its structure is interesting: it essentially reproduces the four points the Tosefta makes, in the same order of appearance, but precedes these by the third reason of the Mishna ("that the minim [heretics] might not say, there are many domains in heaven")—which is duplicitous unless the Talmud's Mishna did not originally feature this reason, or the Tosefta, or a similar, transitory tradition once did.

Thus having commented on all four reasons, the gemara gets to grip more determinedly with the last of these, attentive to the aspects of God's unicity, Adam's creation, and assorted heretics. After a series of associations with Adam's creation as the leitmotiv, and followed by a lengthy series of statements on heretics, emperors and more heretics, as well as the question whether the downfall of the wicked leads to undiluted joy, a mnemonic of four Adamtraditions is cited. Ascribed to Rav Yehuda in the name of Rav, this block is the focus of the remainder of this essay. Whether these and other statements ascribed to Rav Yehuda in the name of Rav were really ever uttered by either of them, or in this form, will not detain us here; below I will use the shorthand 'Rav' for 'Rav Yehuda in the name of Rav'.

The mnemonic of Rav

While this block of four traditions ascribed to Rav (b. San. $38 \mathrm{~b}$ ) corresponds to the four reasons in the Mishna for creating Adam as a solitary being, they simultaneously relate to Psalm 139, deemed to have been spoken by Adam, and Genesis 1:26-27, the creation of the androgyne Adam. A mnemonic note before these traditions marks only the first three of them (שעה בסוף ארמי סימן). Given the shared attribution to Rav Yehuda in the name of Rav, the fourth and final tradition was probably dropped in this marker, either because of homoioteleuton (מין סימן), or because the fourth tradition constitutes the first in a chain of many traditions about heresy and heretics and may accordingly have been considered as part of that cluster of traditions. ${ }^{30}$ Moreover, the manuscript evidence would seem to confirm that all four

${ }^{29}$ So MSS Yad HaRrav Herzog 1; Munich 95; Florence II.I.8-9. The Vilna edition reads "Sadducees" instead.

3o The current position of the fourth tradition is probably not original; see below. 
constitute a cluster. Whilst the mnemonic note for the first three is not preserved in all manuscripts (such as the Munich Codex or Codex Florence), in MS 1 of the Yad HaRav Herzog Institute all four traditions are marked (בימן שעה) בסוף ארמי מין . Since the simanim were wont to disappear at the hands of the scribes who no longer needed such oral techniques for conservation, as Eliezer Segal demonstrated for tractate Megilla, this latter reading is probably original. ${ }^{31}$ If the Talmud links these four traditions by catchword, it indicates that they belong together; but what does that mean? By common consent, not much, if anything at all. Segal considers these markers as a type of Masora to the Talmud, which are "not important for the understanding of the contents of the sugya." ${ }^{2}$

With or without the marker, the inner coherence of series is problematic. ${ }^{33}$ Strings of traditions which share the attribution to a particular sage occur frequently in the Talmud. Halakhically, and for good reasons, such series are often conceived as associative digressions; they are not considered for their connections, often not even at a literary level.

A transparent case is to be found in b. Meg. $3 \mathrm{~b} / 4 \mathrm{a}$, where we find eight statements attributed to R. Joshua ben Levi. In some manuscripts, these have been introduced by the marker siman, but not so in the standard edition. ${ }^{34}$ All eight traditions have some bearing on the reading of the megilla, the scroll of Esther, during Purim, but only the first one relates to the main halakhic topic, that of a status of an inhabited place and the date on which reading the megilla is due. This tradition concerns the status of a village nearby a walled city. Cities walled since the days of Joshua ben Nun read Esther on the fifteenth of Adar, whereas villages read the scroll on the fourteenth. The tradition in question determines what status a village that is very near such a walled city has in respect to the day the megilla should be read. Among the following 7 traditions the first four still concern the status of cities, namely cities whose walls were erected after habitation started and not prior to inhabitation; cities without ten unoccupied men; cities whose walls were laid waste; and finally the status of

\footnotetext{
31 $\quad$ E. Segal, מסורות הנוסח של בבלי מגילה (The Textual Traditions of Tractate Megillah in the Babylonian Talmud) (unpublished PhD thesis, Jerusalem 1981), 103-107. He concludes that there are about 40 such markers in all textual witnesses in the tractate, 29 of which have been preserved by a Yemenite MS, followed by 12 in the Sefardi Göttingen 13, and 10 in Munich 95 and Montefiore 88.

$3^{2}$ See Segal, מסורות הנוסח, 103 n.1. See also: J. Kaplan, The Redaction of the Babylonian Talmud (New York 1933), 230-233; P. Cohen, ספר הסימנים השלם (London, 1953).

33 L. Jacobs, Structure and Form in the Babylonian Talmud (Cambridge: Cambridge University Press, 1991), 46: "The linking of diverse topics solely because they have a common authorship is a frequent literary device in the Babylonian Talmud, and the attempts by commentators to find a linking theme in such instances is misguided."

34 Moreover, according to two genizah fragments the last four of these statements are attributed to Rabbi via R. Joshua ben Levi.
} 
three specific places (Lod, Ono and גיא החרשים). The last three traditions continue the topic of reading the megilla. ${ }^{35}$ In spite of these seemingly blatant connections, Rashi maintains that the second tradition relates to the issue of the Jubilee year and not to the status of a walled city in connection with reading the Scroll of Esther. His argument is based on the proof text for this statement, Lev 25:29, which is indeed related to the Jubilee, yet this is rather obviously not the focus of the statement. Whilst the Ritva, Rashba and Tosafot do not follow suit, Rashi's reading highlights the fact that even within a context which so strongly relates all eight traditions to reading the Scroll of Esther, while seven of them are invariably taken as such, one of them might be conceived of as an isolated discussion of an unrelated topic. One might even add, that the dissociated tradition shares keywords with the preceding and following discussion (settled cities, walled cities). ${ }^{36}$

Rashi's opinion is possible on the assumption that some traditions represent non-topical, but linked additional information that is thrown in for the sake of preservation. There is a logistical reason for this assumption: traditions of important rabbis were collected and memorized in his name in order that they would be preserved for future generations. Sometimes such collections are inserted en bloc for the very reason that they may have been memorized integrally. But in many cases, such clusters are incomplete: other traditions that could have been included are in fact left out. In this particular instance, such an assumption begs the question why these four traditions were selected instead of others with the same attribution. There are close to 400 memroth attributed to Rav Yehuda in the name of Rav, ${ }^{37}$ among which there are others dealing with the creation and with Adam the First..$^{38}$ This points to a considered selection from among available traditions rather than a random process of inserting an entire block for just one relevant tradition that piggybacks others. If selection took place, what was the selective criterion or the organizing principle? Perhaps form follows function, in that the mnemonic marker is not without import for the meaning of a sugya after all. I do not argue that the

35 Women must read the megilla, studying the subject when Purim coincides with the Shabbath, so that the actual reading will be advanced - the duty to read the megilla both in the evening and in the day.

${ }^{36}$ Previously, I discussed some simanim in b. Meg. 25b and 2b-3a (see W.F. Smelik, Rabbis, Language and Translation in Late Antiquity (Cambridge: Cambridge University Press, 2013), 207-210, 477.

37 The number is derived from M. Margoliouth, לחכמי התלמוד והגאונים (2 vols.; Tel-Aviv: Yavneh, 2000), 2.163. A search in the Bar-Ilan Responsa Project CD-ROM gave a number in the 360 's. There are of course variant readings; for example, at the bottom of b. San. $37 \mathrm{~b}$ the tradition attributed to Rav Yehuda about the atonement of exile is attributed to Rav Yehuda in the name of Rav in MSS Munich 95, TS F2(1) 2 and Rav Herzog 1, whereas Florence II.I.8-9 supports the Vilna edition.

$3^{8} \quad$ Among others, b. Hag. 12a; b. San. 59 b and b. B. Bat. 75a. 
merely associative, mnemonic reasons will not be upheld in many cases; I simply like to point out that we cannot always take such reasons for granted.

Here, I will argue that the four traditions attributed to Rav Yehuda in the name of Rav do not represent digressions, but instead relate one by one to the four reasons the Mishna gave for creating Adam as a solitary being. Not only do they, therefore, squarely address issues in the Mishna, but they also redeploy traditions about the First Adam in ways similar to the use of recycling in the Mishna itself. As such, the mnemonic in San. $38 \mathrm{~b}$ assumes more relevance than has been assumed previously.

\section{A Destructive Creation}

The Mishna's first reason for Adam's solitary creation is to teach that the destruction of a single soul is tantamount to the destruction of a full world, and vice versa saving one soul is saving an entire world. Likewise, the core elements of Rav's first statement involve destroying and saving, yet in a different way, as Rav questions the rationale of human existence:

Rav Yehuda said, Rav said, When the Holy One, blessed be He, sought to create Adam, He created a contingent of ministering angels. He said to them, Is it your will that we make Adam in our image?

They answered before Him, O Master of the World, what will be his deeds?

He said to them, Such and such will be his deeds.

They said before Him, O Master of the World, 'What is humankind that You mind it, Adam's offspring that You care for it?' (Ps 8:5)

He stretched out His little finger among them and burned them.

And so a second contingent.

A third one said before Him, O Master of the World, the first [angels] who spoke to You, what did they accomplish? The entire world, it is all yours, do whatever you wish to do in your world.

By the time of the humans of the flood generation and the humans of the generation of the division [of the Tower of Babel] whose deeds were corrupt, they said before Him, O Master of the World, did not the first [angels] speak well before You?

He said to them, 'Even to [your] old age I am He, and even to [your] gray hair will I uphold [you]' (Isa 46:4).

The opening reveals what is at stake in Adam's initial creation: God consulted some angels, specifically created for this purpose, whether to create Adam "in our image" or not. The midrash evidently takes its cue from Gen 1:26, "And God 
said, 'Let us make Adam in our image, after our likeness,'" a text that raised two questions: how do we conceive of, and explain, the creation of humanity in God's likeness, and to whom does "us" refer in "let us make?" Both questions are addressed here. The first answer is, that "we" applies to God and the angels He consulted. But this provisional answer only scratches the surface of this unit, for the real issues come to light in the dialogues, above all in the scriptural quotations, typically in those words from the proof texts which are left unsaid. He creates three bands of angels not just to eventually stick to his original plan, but also to demonstrate that there is no real pluralism in heaven, as Gen 1:26 might have suggested.

God's question must have captured its intended audience with a remarkable twist to the original wording of the creation narratives, as the Almighty here is a challenged and possibly wavering ruler, who needs to know what his angels would prefer that He did. ${ }^{39}$ When the angels learn how humankind will behave once created, they question his intended decision: "Master of the World, 'What is humankind that You mind it, Adam's offspring that You care for it? (Ps 8:5).'” Even though the midrash does not actually state that Adam is going to sin, the audience is keenly aware that he will and fills in the gaps. But then God's attitude changes. As a true despotic ruler, who would push aside any of his subservients who reply unfavourably, He destroys these angels with their negative message: "He stretched out His little finger among them and burned them."

Using repetition to raise the tension, much like the three dispatches which King Ahazyah sent to Elijah in 2 Kings 1, God destroys two bands of angels until the third band wisely decides to bite their angelic tongues. They live to see Noah's ark and the Tower of Babel and only then remind God of the first angels' advice without repeating it.

So is God doubtful of his decision in this narrative? In fact, whereas He would seem to regret his decision in Gen 6:6, not so here. The angels quote Ps 8:5 to denounce humanity even before its coming into existence and suggest its subsequent and inevitable failure. But this psalm in fact demonstrates God's intentions with humanity. Perpendicular to the meaning which the angels imply, humanity is God's majestic representative on earth; the angels do not quote the next verse, "that You have made him little less than divine, and adorned him with glory and majesty" (Ps 8:6). The critical impact of the angels' response is negated by their own proof text, a psalm praising the creation in terms that betray nothing of mankind's frailty, suffering, and sin. The answer which is not given is as important as the one that is. And when humanity

$39 \quad$ In Midrash and Theory: Ancient Jewish Exegesis and Contemporary Literary Studies (Evanston: Northwestern University Press, 1996), 88-90, David Stern compared the portrayal of God in Bereshit Rabbah 8:3 (a close parallel to this unit) to the contemporary, imperial ruler who fears his own counselors and subordinates. 
eventually goes astray, God retorts with the words of his own prophet (Isa 46:4) to wit that He endures human beings with all their imperfections as a loving and caring parent. Again, the relevant part of the quotation is omitted: $:^{40}$ "I have made, and I will bear; and I will uphold and rescue." God suffers man's failures but remains supportive, patient, and forgiving. This dialogue enables the midrashist to express God's unwavering support for the creation of humanity.

Why was humanity created singly? The question triggers the complex issue of singularity and plurality in creation, since Gen 1:26 famously raised the issue of multiple powers in heaven. Adam's singleness demonstrates that God himself is single and unique. ${ }^{41}$ When Targum Onqelos to Gen 3:22 translates יחידי Adam's having become 'like one of us', Adam is defined by the word "single;" his singularity is related to the image of God.

There are further resonances present in this short unit. On a literal understanding of Ps 8:6, Adam was little less in size than God himself; as Kugel puts it, a "huge celestial humanoid." ${ }^{42}$ The gigantic Adam is what making the human in God's image implied, and what connects mishna and memra. The proof text, however, has a different twist in this context. We should not allow the background, use, and connotations of these traditions elsewhere to colour their present redeployment. In this connection it is important to distinguish between an elliptic, or adumbrated quotation and the reuse of a motif which may not carry its original charge. In their sarcastic quotation of Psalm 8, the angels suggest that the creation would be better off without humankind. For God, humankind and world belong together. Rejecting the creation of Adam is denying the world something that ties it to God. God will forgive, he will not destroy the world for the sake of humanity. Rather than portraying a despotic ruler, this midrash highlights the real and almost divine value of human existence and the never-ending length of God's compassion. ${ }^{43}$ The midrashist thus plays with the mishnaic point that Adam was created singly 'to teach you that whoever destroys a single Israelite soul is deemed by Scripture as if he had destroyed a whole world', and vice versa. It is not the human blueprint that is shredded, but any angelic company that suggests abandoning the plan is consumed by God's fire.

\footnotetext{
$4^{40}$ In addition to the unquoted words from Ps. 8 above, the allusion to Gen 1:26 in the very beginning of this unit likewise omits the crucial part, namely "in our likeness".

${ }^{41} \quad$ See also L. Teugels, "The Creation of the Human in Rabbinic Interpretation," in The Creation of Man and Woman: Interpretations of the Biblical Narratives in Jewish and Christian Traditions (ed. G.P. Luttikhuizen; Leiden: Brill, 2000), 107-127.

${ }^{42}$ J.L. Kugel, Traditions of the Bible: A Guide to the Bible As It Was at the Start of the Common Era (Cambridge: Harvard University Press, 1996), 84; cf. A.F. Segal, Two Powers in Heaven: Early Rabbinic Reports about Christianity (Leiden: Brill, 1977), 110-115.

43 This first unit does not quote or refer to Psalm 139, unlike the ones that follow, although this psalm would fit well as it is very suggestive of God's continuing compassion with Adam; more on this psalm below.
} 
The building blocks may not have been Rav's own composition, but he orchestrated motifs and extant interpretations to comment upon the mishna, and to emphasize the value of human existence. Something of the old use is transferred to the new context: God did not have a helper, God takes counsel as contemporary rulers do. But the emphasis is on God's unwavering support for the creation of humanity.

\section{Big in Eden}

According to the Mishna, Adam was created singly for the sake of harmony, since his parenthood applies to all human beings, ${ }^{44}$ hence "someone should not say to his fellow, my father is greater than your father": all are united in Adam. In the Talmud, a different direction is taken. Rav's statement links this part of the mishna to the well-known motif of Adam as a world-spanner, which the Mishna indubitably implies but never made explicit. In truth, Adam was bigger than anyone could have ever imagined:

Rav Yehuda said, Rav said, Adam the First extended from one end of the world to the other, as it is written, 'Since the day that God created Adam upon the earth, even from the one end of Heaven unto the other [has anything as grand as this ever happened, or has its like ever been known?]' (Deut 4:32). ${ }^{45}$

Once he turned sour, ${ }^{46}$ the Holy One, blessed be He, laid His hand upon him and diminished him, ${ }^{47}$ as it is written, 'You have hemmed me in behind and before, and laid your hands upon me' (Ps 139:5).

Taking God's creation of "anything as grand as this" in literal fashion-and note that once again the crucial part of the scriptural text has not been quoted $^{48}$ - , Rav read Adam's dimensions into this grandest thing whose initial

\footnotetext{
44 See also t. San. 8.4; y. San. 4.12(5), 22b; b. San. 38a.

45 Contrary to the common assumption that partial quotations start with the beginning of the verse and omit, even when relevant, the remainder, as in the verses cited in the previous unit, here (and elsewhere) the quotation does not start with the beginning of the verse. It does in the parallel passage of b. Hag. 12a, because the beginning contains a catchword (שאל) relevant for Hag. 12a, which does not apply here.

${ }^{4} \quad$ Lit. "once he stank," that is "became offensive," i.e. "sinned."

47 In the parallel passage of b. Hag. 12a, T-S F 2(1).1 (Cambridge) reads ומיעטו instead while Harl. 5508 of the British Library conflates both readings: ומיעטו והעמידו על מאה אמה Most of the textual witnesses for Hag. 12a support the reading that is attested in b. San. $38 \mathrm{~b}$.

48 Namely, the fact that Adam's original size has never occurred again.
} 
size spanned the world from one end to another. ${ }^{49}$ Boasting that my father is bigger than yours is futile-which is the first purpose of the midrash-unit, but only half the message, and above all the link to what follows. The other half is a probing question into humanity's likeness to God in the face of its humble real-life appearances. If Adam was created in God's likeness, how can this creature be that small and insignificant? In what follows, Rav answers this question: when Adam sinned, God reduced his original dimensions to size. From the little finger that destroyed the angels, Rav now moves to the palm of God's hand shrinking Adam.

Beneath the already serious aspect of the likeness with God that Rav considers in the first interpretation, lurks another major issue which he nor the anonymous voice touch upon. Following the rejection of any esoteric interest in the cosmos, the creation, and the end of days in m. Hag. 2:1, the Talmud (b. Hag. 12a) quotes the very same words of Rav discussed here for San. 38b, but in view of a different topic, namely celestial speculations. In that co-text, Rav cites Deut 4:32 to drive home the restrictions imposed on human speculation: any attention to what is contained in this world, from one end to the other, is allowed, but beyond its border-lines lays forbidden territory. Probing into what preceded this world or what will follow it, what is above or below it, is strictly off limits..$^{50}$ Still in b. Hag. 12a, it is immediately followed by a second tradition cited in the name of Rav Yehuda in the name of Rav, ${ }^{51}$ about the ten things created on the first day of the creation week, which suits the discussion in b. Hag. 12a, but not that of b. San. $38 \mathrm{~b}$, and so this tradition has not been selected in b. San. 38b, whereas the three additional sayings in San. $38 \mathrm{~b}$ are not selected in b. Hag. 12a. Further down at the same folio a third tradition about the creation of the world is cited in the name of Rav Yehuda and Rav, again not mentioning Adam the First. It follows that the sequence of statements in the name of the same rabbis are selected and deliberate rather than the result of a snowball effect, the arbitrary consequences of an associative transmission process.

In San. 38b, a different interpretation of Deut 4:32 in an otherwise similar tradition follows that of Rav:

49 For the idea that the ends of heaven and of earth were coterminous, see J. Tigay, Deuteronomy (The JPS Torah Commentary; Philadelphia: The Jewish Publication Society, 1996), 55. For the use of the same proof text in Gen. R. §8, see Aaron, "Imagery of the Divine," 12.

$5^{0} \quad$ See Ber. R. 1:10; b. Hag. 11b; y. Hag. 2:1, 77c. See further G.E. Loewenstamm, Comparative Studies in Biblical and Ancient Oriental Literatures (Neukirchen-Vluyn: Neukirchener, 1980), 122-136.

${ }^{51} \quad$ In MS Oxford Opp. Add. 23, R. Yirmeya takes the places of Rav Yehuda. 
R. Eleazar said, Adam the First reached from earth to heaven, as it is written, 'Since the day that God created Adam upon the earth, and from one end of the Heaven [to the other]' (Deut 4:32).

Once he turned sour, the Holy One, blessed be He, laid His hand upon him and diminished him, for it is written, 'You have hemmed me in behind and before' etc. (Ps 139:5).

But these verses contradict each other!

Both this and that [distance] have the same measurement. ${ }^{52}$

This is a typical talmudic sequence offering another take on the same two scriptural verses as Rav interpreted above, while commenting upon possible contradictions between these two juxtaposed interpretations. This second take, however, interrupts the mnemonic, as happens frequently with talmudic mnemonics, indicating that the mnemonic itself consolidated prior to the final text.

Tellingly, the tradition attributed to Rav Yehuda in the name of Rav and that attributed to R. Eleazar-which occurs in both tractates-occur in reversed order in b. Hag. 12a, because its context in that tractate requires a primary focus on R. Eleazar's interpretation. Thus in b. San. $38 \mathrm{~b}$ the unit concludes with R. Eleazar's memra, in b. Hag. 12a with Rav Yehuda's memra.

The answers considered in m. Hag. 2:1 and its gemara but not supplied in b. San. 38b, whether deselected, unbeknownst or overlooked, are as interesting and contextually relevant as those readings which have been selected. In Sanhedrin, the focus is literalist: Adam was this world all on his own. That suits the co-text of m. San. 4.5: killing a human being is destroying a world. But the literalist mode, while serious in its pondering of creation and likeness, is simultaneously a catharsis for the pressures of esoteric mysticism. The linking motif between b. San. $38 \mathrm{~b}$ and b. Hag. 12a is Adam's size, stretching from one end of the world to the other end. In Hag. 12a the two memroth of Rav Yehuda in the name of Rav relate to the preceding and following discussion on the leitmotiv of heaven and earth. Only the first applies to Adam HaRishon, whilst all the others are relevant to Hag. 12a's own theme. This co-textual fit illustrates the transmission of such traditions, which often share either a common attribution to a named Sage or the same proof text, before these traditions were selectively applied to their new focus, their new co-text.

Did Rav or Rav Yehuda know any of the conglomerations of the statements that are attributed to them? We cannot answer this question with any degree of certainty, nor do we know whether they authored or uttered any of these memroth themselves, in their present or in another form, on separate occasions or joined together as a unit, with or without additional memroth known from

${ }^{2}$ Namely, the distance between earth and heaven is identical to that between the ends of heaven. 
elsewhere and attributed to them. What we can say is that two observations made above, on the focus and selection of these attributed traditions, argue against their unmediated authorial import. The application of collective statements to their new co-textual focus and the selective use of memroth from among available traditions ${ }^{53}$ suggests that somewhere down the line of textual transmission later tradents or editors were responsible for the collective use of these memroth. ${ }^{54}$ If the juxtaposition and concatenation of memroth is the result of editing at the formative stage of the units, while neither Rav, nor his pupil Rav Yehuda, penned the fourfold midrash as a unit, the responsibility for the selection shifts to a tradent or editor who may, or may not, have known both textual concatenations (in b. San 38 b and b. Hag. 12a). ${ }^{55}$

Another case of bringing traditional exegesis into play with new co-texts is Psalm 139 as cited in Adam's creation narratives. Psalm 139 came to be viewed as Adam's narrative about his own creation, an autobiography of sorts ${ }^{56}$ in which view vv. 5 and 16 are clearly pivotal. With ready-made traditions about his gigantic size at hand, it proved irresistible to read Psalm 139 in related ways. This psalm may not always be placed in Adam's mouth, ${ }^{57}$ but the motif of the erstwhile gigantic, formless Adam towers over every other interpretation. In v. 16 the psalmist exclaims "Your eyes saw my golem (גלמי); they were all recorded in Your book; in due time they were formed, to the very last one of them." The golem is understood to refer to Adam's "unformed limbs," but in reality it is a poorly understood hapax legomenon, perhaps even nothing more than a one-off scribal error for גמלי, "my actions.

53 That is, those attributed to Rav Yehuda in the name of Rav.

$54 \quad$ Wherever block traditions have been realigned and filtered for topical relevance, this is likely to have originated at the formative stage of the sugya, especially if the result demonstrably deviates from previous alignments.

55 My analysis remains at the level of its literary redaction, identifying the choices made and those not made, to chart similarities and dissimilarities, and to pencil a characterization of the apparent purport of the sugya (in its margins with erasers at hand).

${ }^{56}$ It is not certain that this take on Psalm 139 dates from the late Second Temple period, since most of our sources belong to rabbinic literature. In b. Bav. Bat. 14b-15a the contribution of Adam to the Book of Psalms was not believed to require any further specification, but that does not push the date post quem back into the Second Temple period. See also Shir R. 4:5; Qoh. R. 1:17. On the other hand, in the Testament of Adam 13:2 angels worship Adam on the basis of his likeness to God. The talmudic passage is discussed in L. Jacobs, Structure and Form, 31-41.

$57 \quad$ For example, vss. 21 and 22 have been attributed to David in b. Shab. 116a; v. 11 to David in b. Pes. 2b. V. 13 might well have induced assumptions about another author than Adam, since it refers to "my mother's womb."

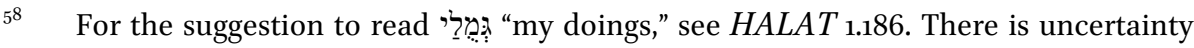
about the root; with the exception of Syriac لحلs "rocky, uncultivated soil" and Arabic ugalama "to cut off," there is little indication that this might be a Hebrew root; cf. M. Sokoloff, A Dictionary of Jewish Babylonian Aramaic of the Talmudic and Geonic Periods 
the word golem went on to receive a distinguished reception history, for the unintelligible word (if that is what it was) soon assumed the specific meaning of "unformed blob" or "embryo," and would in the present context be interpreted as a reference to Adam's creation as a huge humanoid. ${ }^{59}$

Ps 139:16 does not figure in this unit, ${ }^{60}$ apparently because the topical focus is not Adam's unformed golem, presupposed as it is, but its reduction to size, which was based on Ps. 139.5. ${ }^{61}$ This latter verse was soon applied to Adam: "You hedge me before and behind (אחור וקדם); You lay Your hand upon me." It is remarkable how versatile these words proved to be in their connection with the androgynous Adam-myth, for the words אחור וקדם were read in three different ways: as physical, geographical or temporal terms. In a physical sense, Sages take אחור וקדם to refer to Adam's initial androgynous status with both a male and female side (b. Ber. 61a; b. Eruv. 18a; Lev. R. 14:1); this motif is connected with the creation of humanity as male and female all at once (Gen 1:27). In a geographical sense, the verse relates Adam's original gigantic dimensions, in which אחור וקדם stand for the full dimension of the world, that is the West and East (while Deut 4:32 could be taken to supply the third dimension). In this interpretation, צרתני is related to the verb יצר "to shape, give form." ${ }^{62}$ The temporal reading is represented by Rav's interpretation in b. San. 38b, in which the verb צרתני צור צn is related to צnd rects the hemming of Adam's original proportions, hence his reduction to size. ${ }^{63}$ This reduction obviously presupposes his enormous initial dimensions. In this approach,

\footnotetext{
(Dictionaries of Talmud, Midrash and Targum, 3; Ramat Gan: Bar-Ilan University Press, 2003), 268; Barc, "La taille cosmique d'Adam," 176.

59 See b. San. 38a. For the meaning “embryo," see Lev. R. 14:8.

6o Barc alerts us to some basic distinctions between the various motifs, without importing to them a common origin in a non-rabbinic myth (for the latter, see now Aaron, "Imagery of the Divine"); Barc, "La taille cosmique d'Adam," 175. However, his contradiction between the gathering of Adam's raw materials and his world-spanning size (p. 177) is falsified in R. Meir's memra of b. San. 38a (bottom), where God's beholding the golem (Ps 139:16) is tantamount to God's eyes "roaming over the whole world" (Zech 4:10) — the "whole world" being synonymous with golem. Also in our fourfold Adamtradition in San. $38 \mathrm{~b}$, the golem-motif is a necessary presupposition.

${ }_{61} \quad$ Perhaps, as Kugel, Traditions of the Bible, 83, suggests, this verse contains a key for the tradition that Adam is the first person in this psalm. The Septuagint, Aquila, Symmachus and Peshitta, all take אחור וקדם as the last words of vs. 4, not the first of vs. 5 . These words therefore are not spatial, but temporal, "You know it all, the last things and the first." The temporal sense would allow the next few words, "you formed me," to be read as the very first act of creation. Note that there are also explicit statements about Adam being the last act of creation.

62 $\quad$ Ber. R. 8:1; 21:3; 24:2; Lev. R. 18:2; Midr. Tan. B. בראשית. In some of these texts, East/West is supplemented with North/South on the basis of Deut 4:32.

${ }_{3}$ Gen. R. §8:1; b. San. 38b; b. Hag. 12 a.
} 
אחור point to "before" and "after" Adam's heresy in a temporal sense. ${ }^{64}$ Alternatively, the different periods refer to this World and the World to Come; ${ }^{65}$ or to Adam being the first act of creation, as a formless mass, and all the same the last act, as a completed human soul. ${ }^{66}$

Some of these interpretations may deliberately steer the reader away from the mythological roots of these motifs. That possibility prompts the question of which came first, the motif of Adam as an oversized embryo or the corresponding interpretation of the Psalm? While it stands to reason that an existing motif was transferred to Psalm $139,{ }^{67}$ there is no need to choose. Given the availability of the motif of a macrocosmic God in the surrounding pagan culture ${ }^{68}$ in combination with scriptural verses that required explanation (Gen 1:26-27; 5:1-2) and which lent themselves easily as readings in support of the motif, the question of priority is largely unimportant. Far more interesting is the variation of takes on the proof text, which shows how both proof texts and motifs could be resignified.

\section{Adam the Heretic}

If the four Adam-traditions in this sugya indeed correspond to the four reasons of m. San. 4:5, they must have been rearranged slightly: the final memra concerning Adam's heresy corresponds to the third reason in the Mishna (about the minim), whereas the third memra in b. San. 38 b corresponds to the fourth reason in the Mishna. The order of the last two traditions may have been inverted, since the Talmud continues with a long series about heresy and heretics, hence an editor could have changed the order of Adam-traditions accordingly. On the other hand, lateral links are frequent in talmudic sequences and rearrangements the order of the day in productive textual transmission of this kind, as the parallels attest between Mishna, Tosefta, Palestinian and Babylonian Talmud of the four reasons. Without taking a stand on this, I follow the mishnaic order for the sake of convenience.

\footnotetext{
64 The Septuagint, Aquila, Symmachus and Peshitta all take the words אחור וקדם as the final part of vs. 4, which creates another type of temporal sense, ידעת כלה אחור וקדם "O Lord, You know it all, the last things and the first."

65 Midr. Tan. B. תזריע 2; Lev. R. 14:1.

66 Ruth R. 7. As a gigantic humanoid, Gen R. §8:1.

${ }_{67}$ Aaron, "Imagery of the Divine." Kugel, Traditions of the Bible, 83-84, cautions that the motif of a gigantic Adam may have been triggered by a textual analysis of Gen. 1.26 which resembles Adam to God; if so, the androgynous first human being would be a polygenetic motif in Jewish and non-Jewish sources. However, given the temporal priority of the non-Jewish sources as well as the Greek loanwords in the Jewish versions, Kugel's purely biblical origin of the myth is unlikely.

${ }^{68}$ See above, n. 2.
} 
The fourth tradition in this siman identifies Adam the First as a heretic, which relates to the third reason in the Mishna, "(Therefore Adam was created singly), so that the heretics should not say, There are many domains in Heaven":

Rav Yehuda also said in Rav's name, Adam was a heretic, for it is written, 'And the Lord God called unto Adam and said unto him, "Where are you?"' (Gen 3:9) i.e., Where did your heart turn?'

On a superficial reading of God's question (“Where are you?") God appears not to have known Adam's whereabouts. ${ }^{69}$ To avoid this impression, Targum Neofiti interspersed God's question with a pre-emptive explanation, "Now listen, the whole world which I created is manifest before me, darkness and light are manifest before me, and you think that the place where you are is not manifest before me?" ${ }^{70}$ Hence God's omniscience impels the targumist to bring another understanding to God's question, to wit, "Where is the commandment [not to eat from that tree] that I commanded you?" God already knows the sin Adam committed; He only requires Adam to own up to it and to come out of hiding..$^{1}$

Neofiti's reasoning reveals the sensitivity which undoubtedly underlies Rav's interpretation as well. God had no desire to learn where Adam was holding up physically. In truth, He questioned Adam's loyalty when he asked for his whereabouts: Whose side are you on? But Rav's take differs from Neofiti, if ever so slightly, by identifying Adam's sin as heresy rather than the transgression of a specific commandment. The exact form his heresy took is left open-perhaps because it consisted of the very sin he committed, which required no further specification ${ }^{72}$ - but it does not seem to matter. Sure enough, the Talmud

${ }_{9} \quad$ This cannot be the full meaning, since (a) Adam immediately answers, despite hiding and (b) the interrogative noun איה implies knowledge mingled with a certain reproach (if one really does not know where someone is, איפה is used). See B. Jacob, Das erste Buch der Tora: Genesis (Berlin: Schocken, 1934), 109.

$7^{70}$ My translation after the facsimile edition: The Palestinian Targum to the Pentateuch: Codex Vatican (Neofiti 1) (Jerusalem: Makor, 1970), 6 (cf. the marginal variant reading).

${ }^{71} \quad$ See also M.L. Klein, The Fragment-Targums of the Pentateuch According to their Extant Sources (AB 76; Rome: Biblical Institute, 1980), 46, 127.

$7^{2} \quad$ In b.San. 56b, Rav Yehuda returns to the first sin and identifies it as idolatry (followed by another statement attributed to Rav Yehuda in the name of Rav). Cf. Tertullian, Adversus Marcionem, 2:2: "For can anyone hesitate to describe as heresy, or choosing, that transgression of Adam which he committed by choosing his own judgement in preference to God's?| (translation quoted after E. Evans, Tertullian: Adversus Marcionem [Oxford: Oxford University Press, 1972], 91). 
interpolates two explanations suggesting either epispasmos or polytheism, but these traditions are not an integral part of the mnemonic's series. ${ }^{73}$

Likewise, Rav differs from early Christian motifs that portray Adam as an earthly sinner, in which capacity the first human ( $\left.\delta \pi \rho \omega \tau \sigma \circ \alpha^{\prime} \nu \theta \rho \omega \pi \circ \varsigma^{\prime} A \dot{\delta} \dot{\alpha} \mu\right)$ is contrasted with Jesus. ${ }^{74}$ Rav's point is different, because he (or the editor responsible for the selection of traditions) focuses on heresy for a good reason. Following the mishna, Adam was created singly to prevent heresy and teach that there are no other powers in heaven but the One God of Israel. When the talmudic layer came to be added to the mishnaic tradition, it is more than irony to put the First Adam down as the first heretic. Taking the heresy to Adam, the midrash avoids any attribution of heresy to any other higher authorities, lesser divine beings or divine rivals. It follows that the editor underscores the single domain of authority: there is no other god which authored evil and heresy, just as there is no other god to which Adam could have turned. Whose side are you on, Adam, becomes a taunting question when there is no other power to turn to. It is rhetorical not just in the sense that God obviously knows where Adam is, but rhetorical too, in the sense that he cannot turn to any other power. ${ }^{75}$ As the upshot of all this, of course, Adam is heretical and yet created in the image of God.

\section{Bilingual Adam}

From the fact that Psalm 139 deals with the creation of humankind, and uses one or two perceived Aramaisms in what was taken to represent Adam's direct speech, Rav Yehuda and Resh Laqish deduce that Adam spoke Aramaic:

73 Both interpolations are attributed to second generation Babylonian Amoraim, thus contemporaries of Rav Yehuda. The first is a comment by R. Isaac in the form of Hosea 6:7: "R. Isaac said: He practised epispasmos: For here it is written, But like man, [Adam] they have transgressed the covenant; (Hos 6:7) whilst elsewhere it is said, He has broken my covenant" (Gen 17:14). Once more, the proof text is lacunose: the full text of Gen 17:14 will illuminate the reference to reversing the signs of circumcision: "And if any male who is uncircumcised fails to circumcise the flesh of his foreskin, that person shall be cut off from his kin; he has broken my covenant." Alternatively, Adam was a polytheist: "R. Nahman said: He denied God. Here it is written, They have transgressed the covenant; whilst elsewhere it is stated, [He has broken my covenant, (Gen 17:14) and again,] Because they forsook the covenant of the Lord their God [and they bowed down to other gods and served them] (Jer 22:9)."

$74 \quad 1$ Cor 15:45-47; Rom 5:14. Cf. Y.Y. Teppler, Birkat haMinim: Jews and Christians in Conflict in the Ancient World (TSAJ 120; Tübingen: Mohr Siebeck, 2007), 303-304.

75 There is no connection with Psalm 139, unless one was lost in the process of editing. The Psalm repudiates idol worship. Dahood argues that this psalm may have been composed by a leader who was charged with idolatry; M. Dahood, Psalms III: 101-150 (Garden City: Doubleday, 1970), 284. The Targum takes vs. 24 as a reference to the speaker's idolatrous ways. 
Rav Yehuda also said in Rav's name, The first Adam spoke in the Aramaic language, for it is written, 'How difficult are your thoughts to me, O God' (Ps 139:17). ${ }^{7^{6}}$

At face value, this memra has no intrinsic connection with the preceding and prevalent motifs of the world-spanner or the golem, in fact no parallel with any known tradition anywhere else at all. Except that Adam is a dichotomy like he was in each of the previous instances: not just male and female, huge and insignificant, God-like and heretical, he is also bilingual, as he's clearly speaking Hebrew and Aramaic. There is an immediate link with the fourth reason in the Mishna, for God's grandeur is to mint all people with a single seal, yet no one is alike anyone else: His singularity produces plurality.

This unit starts with the notion that Psalm 139.17 contains Aramaic, without identifying which word(s) represent the Aramaic or Aramaism(s). The focus is on the two words יקרו "they are heavy, precious"77 and רעיך "your thoughts, friends", both of which have long been deemed Aramaic loanwords. ${ }^{78}$ The rabbis were aware of such loans; for example, in b. Meg. 9a the Aramaic loanword פתגם 'honour' 'decree' in Est. 1.20 within an otherwise completely Hebrew verse are identified as 'targum' (=Aramaic) 'written in Scripture'. Whether Rav pointed out both words as Aramaic (as assumed in my translation above) remains inconclusive. Without further explanation, the point of Rav's quotation of Ps. 139 remains opaque apart from the inference that Adam spoke Aramaic. Because most of the verse, let alone the psalm, is written in Hebrew, bilingualism is implied.

The anonymous voice then equates Rav's interpretation with an observation by Resh Laqish which sheds a fuller, but slightly different light on the verse:

And is this not what Resh Laqish said, What [does it mean] when it is written, 'This is the book of the generations of Adam' (Gen 5:1)? This conveys that the Holy One, blessed be He, showed him [that is, Adam] every generation and its expositors, every generation and its sages. By the time of the generation of R. Aqiva, [Adam]

\footnotetext{
${ }^{76}$ This adapted English translation reflects the talmudic interpretation.

77 This could be read in the light of Ps 116:15, "Heavy [or, precious, יקר] in the sight of the LORD is the death of His faithful ones." So in the Yelamdenu Midrash; see L. Grünhut, ספר הליקוטים (6 vols.; Frankfurt am Main: I. Kauffmann, 1898-1903), vol. 4, f. 54a.

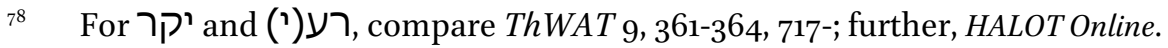
See further the translation of Hebrew רעה in LXX Isa 44:28. For רעה as 'friend' in Aramaic (a Hebrew loan!), see B. Porten and A. Yardeni, Textbook of Aramaic Documents from Ancient Egypt (Winona Lake: Eisenbrauns, 1986), C1.1, 161.
} 
rejoiced at his Tora [learning] but mourned over his death. He said,

'How precious are your friends to me, O God.'

Before dwelling on the hermeneutics of this passage, it is worth pointing out that the rabbis identified here belong to different generations and areas. Resh Laqish was a second generation Palestinian Amora, whereas Rav was a first generation Babylonian Amora (and Rav Yehuda the latter's second generation disciple). It is indeed not Rav or Rav Yehuda but the anonymous voice which connected the two statements. Furthermore, the attribution to Resh Laqish is not consistent, since the application of Ps 139:17 to Adam's vision of future leaders occurs elsewhere with different attributions to Palestinian sages, ${ }^{79}$ who do not belong to one and the same period either. The element common to all these instances extends to the motif of Adam's vision alone, but not to its subsequent application. In fact, the reference to R. Aqiva occurs only in the instances attributed to Resh Laqish. It would therefore be entirely plausible that the motif of Adam being shown all his future generations on the basis of Ps 139:17 belonged to a common tradition, the application of which could be specific and tailored to the topic at hand.

זה ספר Resh Laqish probes the meaning of the 'book' in Gen.5.1, in the phrase ז'This is the book of the line of Adam." This book, he continues, proves that God showed Adam all the future generations of the world, which are his 'line', Adam's offspring. Among those generations that Adam sees, he identifies R. Aqiva as one of God's 'friends' in Ps. 139.17 whose fateful death is heavy to bear while his faithful life is precious to behold - a double interpretation of the verb יקר' as 'precious' and 'heavy'.

The choice of Gen. 5.1 has further implications. As Rashi points out, Ps 139:17 is preceded by a reference to a book in v. 16: "Your eyes saw my golem, and in your book (ספרך) all are written down." So why dwell on Gen. 5.1? Pointedly, the full quotation of Gen 5:1 links Adam's generations to the creation in the likeness of God ("This is the record of Adam's line; [when God created Adam, He made it in the likeness of God]"), including its verbal play on singularity and plurality. The likeness of the One God is reflected in Adam's multiple offspring. It is probably no coincidence that the notion of plurality also chimes with Ps. 139.18 ("I count them - they exceed the grains of sand"). In his dual interpretation of Gen. 5.1 and Ps. 139.17, Resh Laqish epitomizes the Mishna's

\footnotetext{
79 R. Joshua b. Qarha, R. Yehuda bar Simon, and Shimeon ben Laqish (Resh Laqish) in the name of R. Eleazar ben Azarya: Gen R. 24:2; Pes. R. 23:2; b. A. Zar. 5a; SOR 30; ARN A 31. Moreover, the same notion of beholding Israel's future leaders occurs in connection with Moses on the authority of R. Yehoshua of Saknin in the name of R. Levi in Lev. R. 26:7. The variant "R. Yehoshua of Saknin in the name of Resh Laqish" in Midr. Tan. אמור 2 would seem to be a misreading of the abbreviation ' ל ר"ל ' ר ' 26:7; Yalq. S. אמור §626; Yalq. S. 1 Sam. §139.

80 See $n .78$ above.
} 
dual focus on Adam's solitary creation in the likeness of God and the plurality of his progeny.

There are possible differences between Resh Laqish and Rav. Whereas Resh Laqish based his on the predominantly Hebrew meaning of רע as 'friend', Rav's interpretation of this word is not secured, as observed above, and could be either 'friend' or the Aramaism 'thought'. Nor is it clear whether Rav played on the double meaning of יקר as Resh Laqish did. It is true that the anonymous voice introduces Resh Laqish as if in agreement with Rav ('And is this not what Resh Laqish said'), but the agreement could simply consist of the view that Ps. 139 reflects Adam's very own words, without relating to Rav's interpretation of (at least one of) these two words as Aramaisms. Ultimately, the element of Aramaic is unnecessary for Resh Laqish's inference, whereas it gives the memra of Rav its direction, namely that the first Adam spoke something else besides the holy tongue.

Rav's claim is significant in light of the Mishna's series on Adam, more specifically, the third reason for creating Adam singly, that God used a single mint which yielded multiple individual coins. Whilst God mints Adam in the Hebrew language-God is universally understood to have spoken the holy tongue at creation, as did the primordial human beings after him-, Adam turns out to speak both Hebrew and Aramaic. Here we have a plurality of "nations, peoples and tongues", encapsulated by the siblings Hebrew and Aramaic, over against the singular origin of both language and humankind. ${ }^{81}$ Early rabbinic thought postulated the existence of a family of languages with Hebrew as its single ancestor, with the 70 languages of the nations being consonant with the One. ${ }^{82}$ More pertinently, the existence of multilingualism is not related to multiple Gods, but to the single seal of the One God, just as heresy could not be related to multiple gods. Aramaic was the necessary linguistic attribute to this universalistic notion.

Once again, Rav's Adam tradition reflects on the mishna and the notion of creation in the likeness of God. Human pluriformity, typified as bilingualism, somehow corresponds to and evolves from God's singularity and Holy Tongue.

\section{Adam Serialized}

Throughout the series discussed here, in Mishna, Tosefta and the Babylonian Talmud, traditions about Adam the First emerge, which circulated in some form or another as blocks of uncertain length, but were reworked by the

81 Syriac Christians, however, held Aramaic for both the primordial language and the Holy Tongue: M. Rubin, "The Language of Creation or the Primordial Language: A Case of Cultural Polemics in Antiquity," JJS 49 (1998): 306-333.

82 Smelik, Rabbis, Language and Translation, 9-41. 
author/editors at various points in the history of their transmission. Altogether, these texts illustrate how familiar the author/editors were with circulating traditions and their freedom of topical selection and adaptation in the formation of new texts. Although the traditions, motifs, themes may have been used as old bricks that were readily available to build something new, the bricklayers did not necessarily follow a loose pattern of composition. Their actual deployment in our texts were subject to the usual processes of authorial selection and rearrangement.

I have assumed throughout this study that any supposedly original, historical context for each of these traditions has been suspended. The giant androgyne of myth has been reapplied to new topics and reshaped for new purposes to such an extent that only its contours are still discernible. The authorial voice aptly reused the myth of the androgyne, gigantic first human being — which, as Aaron has shown, was familiar in rabbinic circles in all its intricate details ${ }^{8_{3}}$ to emphasize a halakhic as well as moral point about the creation of the human. Whatever the origin of the traditions - in the underlying case, speculation about anti-Gnostic or anti-dualistic tendencies has been rife-, they were marshalled for good effect as raw material, realigned to serve new purposes, divested of their original impetus. Oral transmission involved creativity in the instantiation of each text that was to be passed on in a new context, with new textual connections and interpretative slants.

The selective, authorial use of certain traditions begs the question what place associative digressions have in the new textual instantiations. The first two parts of the present study focused on m. San. 4.5 in order two clarify its structure amidst two issues: the reason for the inclusion of the second, seemingly superfluous scriptural interpretation of Gen. 4.10 and the arrangement of the four reasons for Adam's singular creation. In each instance, the Mishna includes pre-extant material that has been tailored to its new purposes. In the process, a scriptural interpretation that once seemed a skippable digression within that new mishnaic co-text emerged as an integral, even pivotal part of the mishna's argument. Both interpretations of Gen. 4.10 appear to have been deployed to express opposite interests in the halakhic topic of witnesses' testimony.

Similarly, in the comparison with the Toseftan parallel it transpired that the Mishna's four reasons involve a reworked text, firmly embedded into its new halakhic co-text concerning the admonishment of witnesses. The Tosefta's list of four reasons presupposes an awareness of some text bearing close resemblance to the Mishna, if only because its very point of inclusion is unclear without access to the Mishna, but it differs in its arrangement and message: the Tosefta's text is a homily on the common ancestry of Cain and Abel to argue against the claim of two different creators.

${ }^{8} \quad$ Aaron, "Imagery of the Divine." 
A similar selection principle is discernible in the four traditions about First Adam attributed to Rav Yehuda in the name of Rav. This series of interpretations is not an index, solely governed by the arbitrary process of association. These four traditions, collectively introduced by a mnemonic marker (siman) in b. San. $38 \mathrm{~b}$, constitute a unity rather than a loose, accumulative collection of tidbits created by sheer associative force. Here we have a midrash in four parts with intricate motifs, neatly woven together, which correspond to the four reasons which the Mishna gave for creating Adam as a solitary being. These four Talmudic statements turn motifs known from speculation about the creation of the First Adam into a homily on Mishna Sanhedrin 4.5, Gen. 1.26-27 and Ps. 139. In reading them together, Rav, Rav Yehuda or the editor established a new relevance for Adam's solitary creation. Thus some of the traditions marked with a mnemonic siman display more coherence than they may have been credited with in the past. ${ }^{84}$

The Mishna emphasized the ethical dimension of Adam's size and singularity, using well-known motifs as its building blocks for an entirely different argument. The first two reasons emphasize the consequences for humanity of humanity's single creation, the last two focus on its implications for our understanding of God as the single, unique Creator. At first sight, the talmudic unit discussed here may not seem to add much more than a few associations with Adam, although taken together, the four talmudic traditions progressively describe the creation of humankind: from God's deliberations with his angels - shall we or shall we not— to the sheer physical mass of Adam's golem, which may or may not have been spirited, to the mature Adam, who is a heretic endowed with speech.

Matching the mishnaic structure, the siman's Adam-traditions display an unmistakable return to some of the pertinent questions surrounding Adam and God, questions prompted by the creation narratives of Psalm 139 as well as Gen. 1.26-27, 3.22 and 5.1. Selecting from the available exegetical options, the four traditions address the likeness of God and humanity following Genesis 1.26-27. This short series would represents a discourse on Adam's creation in God's likeness, adding some of the connotations which were left out in the Mishna, without, however, reintroducing any overtly gnostic or anti-gnostic overtones. The editor underscores the single domain of authority: there is no other god who authored a world full of heresy.

${ }^{84} \quad$ See nn. 30, 31, 32 and 35 above. 